\title{
Profile of patients with rheumatic diseases undergoing treatment with anti-TNF agents in the Brazilian Public Health System (SUS), Belo Horizonte - MG
}

\author{
Haliton Alves de Oliveira Junior ${ }^{1, *}$, Alessandra Maciel Almeida ${ }^{2}$, Francisco Assis Acurcio ${ }^{1}$, Jéssica \\ Barreto dos Santos ${ }^{1}$, Adriana Maria Kakehasi ${ }^{3}$, Juliana Alvares ${ }^{1}$, Clarice Gomes e Souza Dabés ${ }^{1}$, \\ Mariangela Leal Cherchiglia ${ }^{2}$
}

${ }^{1}$ Departamento de Farmácia Social, Faculdade de Farmácia, Universidade Federal de Minas Gerais, Belo Horizonte, MG, Brasil, ${ }^{2}$ Departamento de Medicina Preventiva e Social, Faculdade de Medicina, Universidade Federal de Minas Gerais, Belo Horizonte, MG, Brasil, ${ }^{3}$ Departamento do Aparelho Locomotor, Faculdade de Medicina, Universidade Federal de Minas Gerais, Belo Horizonte, $M G$, Brasil

\begin{abstract}
The aim of this study was to describe the baseline demographic and clinical characteristics as well as the functional status of a prospective cohort of patients with rheumatic diseases assisted by the Brazilian Public Health System (SUS). Data for 302 patients receiving tumor necrosis factor $\alpha$ inhibitors (antiTNF agents) was collected through a standard form. Among patients, 229 (75.8\%) were female and 155 (51.3\%) were Caucasian; the mean age was $50.3 \pm 12.8$ years, and the mean disease duration was $9.9 \pm 8.7$ years. Among them 214 patients $(70.9 \%)$ received adalimumab, 72 (23.8\%) etanercept, and 16 (5.3\%) infliximab. Mean Health Assessment Questionnaire-Disability Index (HAQ-DI) was $1.37 \pm$ 0.67 for all participants. Poor functional response was associated with female gender, married patients and with a score of $<0.6$ on the EuroQoL-5 dimensions (EQ-5D). Significant correlation was found between the HAQ-DI values, disease activity and quality of life (QOL). The results obtained in this study contribute to a better understanding of the clinical and demographic characteristics of patients with rheumatic diseases at the beginning of anti-TNF-agent treatment by SUS. Furthermore, our findings are consistent with another Brazilian and foreign cross-sectional investigations. This knowledge can be of great importance for further studies evaluating the effectiveness of biological agents, as well as, to contribute to improve the well-being of the patients with rheumatic diseases.
\end{abstract}

Uniterms: Rheumatic diseases/treatment/patients profile. Rheumatoid arthritis. Ankylosing spondylitis. Psoriatic arthritis. Brazilian public health system. Anti-TNF agents/treatment of rheumatic diseases.

O objetivo do estudo foi descrever as características demográficas e clínicas iniciais, bem como o estado funcional de uma coorte de pacientes com doenças reumáticas tratados pelo Sistema Único de Saúde (SUS). Dados de 302 pacientes em uso de inibidores do fator de necrose tumoral (agentes anti-TNF) foram coletados por formulário padronizado. Desses, 229 (75.8\%) eram mulheres e $155(51.3 \%)$ eram brancos; a idade média foi 50,3 $\pm 12,8$ anos, e a duração média da doença foi de 9,9 $\pm 8,7$ anos. Entre os pacientes 214 (70,9\%) usaram adalimumabe, 72 (23,8\%) etanercepte e $16(5,3 \%)$ infliximabe. A média do Health Assessment Questionnaire-Disability Index (HAQ-DI) foi 1,37 $\pm 0,67$ para a população total. Pior resposta funcional estava associada com mulheres, pacientes casados e com um valor de EuroQoL-5 dimensions $(\mathrm{EQ}-5 \mathrm{D})<0.6$. Correlação significativa foi obtida entre os valores de HAQ-DI, atividade das doenças e qualidade de vida. Os resultados obtidos no estudo contribuem para o melhor entendimento das características clínicas e demográficas de pacientes com doenças reumáticas iniciando a terapia com agentes anti-TNF pelo SUS. Além disso, nossos achados são consistentes com resultados obtidos em outros estudos transversais nacionais e estrangeiros. Este conhecimento pode ser de grande importância

\footnotetext{
*Correspondence: Haliton Alves de Oliveira Junior. Departamento de Farmácia Social. Faculdade de Farmácia. Universidade Federal de Minas Gerais. Av. Presidente Antônio Carlos, 6627, Campus Pampulha - Bloco 2, $1^{\circ}$ andar, sala 1023 -31270-901 - Belo Horizonte - MG, Brasil. E-mail: halitonjr@hotmail.com
} 
para estudos futuros que avaliem a eficácia de agentes biológicos, assim como, para contribuir para a melhoria do bem-estar das pessoas com doenças reumáticas.

Unitermos: Doenças reumáticas/tratamento/perfil de pacientes. Artrite reumatóide. Espondilite anquilosante. Artrite psoriásica. Brasil/Sistema Único de Saúde. Agentes anti-TNF/tratamento de doenças reumáticas.

\section{INTRODUCTION}

Rheumatoid arthritis (RA), ankylosing spondylitis (AS) and psoriatic arthritis (PsA) are chronic inflammatory diseases that, if not treated properly, can lead to joint destruction and deformity, with subsequent functional limitation and a direct impact on patients' quality of life. In addition to the articular manifestations, these diseases may present with fatigue, movement loss and extra-articular manifestations, such as fever, anorexia and weight loss (National Institute for Health and Care Excellence, 2009; Brasil, 2013).

The prevalence of RA worldwide is approximately 1\% (American College of Rheumatology, 2002; Canadian Agency for Drugs and Technologies in Health, 2006), and it is two to three times more common in women than in men. If untreated, $20-30 \%$ of patients with RA will become permanently unable to carry out their routine activities three years after diagnosis (Canadian Canadian Agency for Drugs and Technologies in Health, 2006). In Brazil, a cross-sectional study of rheumatic diseases have evaluated the prevalence of RA being $0.46 \%$ (Senna et al., 2004). Another Brazilian study has estimated the RA prevalence ranging to $0.2 \%$ to $1.0 \%$ (Marques Neto et al., 1993).

AS has a prevalence of $0.05-0.23 \%$, is more frequent in the second and third decades of life and primarily affects Caucasian individuals who are human leukocyte antigen subtype B27 (HLAB27) positive. Men are affected three to four times more often than women (Sampaio-Barros et al., 2007; West, 1949; Gomor, Gyodi, Bakof, 1977; Carbone et al., 1992) In Brazil, due to widespread miscegenation, it is possible to find mulattos afflicted with AS; however, this disease is quite rare in non-mixed black populations (Sampaio-Barros et al., 2007). AS greatly affects the productivity or functional capacity of an individual (Chorus et al, 2002).

PsA has been defined as a psoriasis-associated inflammatory arthritis (Moll, Wright, 1973). Psoriasis affects $2-3 \%$ of the population, while inflammatory arthritis occurs in $6-42 \%$ of patients with psoriasis (Gladman, 1995).

The introduction of biological therapy to the treatment of rheumatic diseases significantly changed the therapeutic approach to these diseases and the results obtained. Drugs such as adalimumab (ADA) and infliximab (INF) are recombinant monoclonal antibodies that bind to and neutralise the biological activity of tumour necrosis factor $\alpha(\mathrm{TNF}-\alpha)$. Etanercept (ETA) is a fusion protein that also binds to TNF- $\alpha$ and inhibits the action of this cytokine.

Anti-TNF agents for which the efficacy and safety have been demonstrated in the literature (Lipsky et al., 2000; ST Clair et al., 2004) have been incorporated into the Brazilian Public Health System (Sistema Único de Saúde - SUS) since 2002 (Brasil, 2008). The SUS is a universal health care system in which the supply of antiTNF medications follows a rigorous clinical protocol (Brasil, 2013) involving patients' initial consent to receive the drug. However, there is a need for an organised pharmaceutical service that would allow an understanding of the patients' characteristics and follow-up information regarding the long-term therapeutic responses and any intolerance to or adverse events associated with the prescribed drugs.

Some Brazilian studies regarding rheumatic diseases have evaluated functionality, the majority of it in RA patients. The functionality results in these studies show that the Brazilian AR population presents moderate disability without using a biologic therapy (Pinheiro et al., 2013; Da Mota et al., 2012; De Oliveira Junior et al., 2015; De Azevedo et al., 2008; De Souza et al., 2011; Da Mota et al., 2010). Furthermore, some of these studies have presented a correlation between functionality results and disease activity and quality of life (Da Mota et al., 2012; De Oliveira Junior, et al., 2015). According, De Oliveira Junior et al., 2015, patients who present better functionality status in the onset of biologic treatment, tend to present a good quality of life result after six month of therapy.

Belo Horizonte is the capital of the state of Minas Gerais (MG), which is located in the South-eastern Region of Brazil. In 2011, 2.967 patients with these three rheumatic diseases were being treated with biological agents in $\mathrm{MG}$, and 1.280 of them were in the initial stage 
of treatment (Secretaria de Estado de Saúde do Estado de Minas Gerais, 2013).

This study aimed to describe the clinical and demographic characteristics as well as the use profile of anti-TNF agents in patients with RA, AS and PsA who were treated by the SUS in Belo Horizonte. In addition, it intended to evaluate the factors related to the functional capacity of these individuals at the beginning of treatment.

\section{PATIENTS AND METHODS}

This cross-sectional study is an integral part of an open prospective cohort involving SUS patients in the city of Belo Horizonte, MG, Brazil. The study included patients diagnosed with RA, AS and PsA who had approved applications for ADA, INF and ETA and who received the first dose of the drugs after the initiation of the cohort. The data were collected from March/2011 to February/2013, and only the first interview (baseline data) was considered for the present study.

For approval in the application process, the patients must meet the respective specific qualifying criteria: the American College of Rheumatology (ACR) 1987 (Arnett et al., 1988) for patients with RA; the New York criteria (Van Der Linden, Valkenburg, Cats, 1984) for AS patients; and the Classification Criteria for Psoriatic Arthritis (CASPAR) (Taylor et al., 2006) for patients diagnosed with PsA.

According to the Clinical Protocol and Therapeutic Guidelines for AR, INF is recommended at a dose of $3 \mathrm{mg} / \mathrm{kg}$, administered intravenously every 8 weeks; at the beginning of the treatment, a loading dose should be used in three applications as follows: at baseline and after 2 and 6 weeks respectively. ETA is recommended at a dose of $50 \mathrm{mg}$, administered subcutaneously once a week. ADA is recommended at a dose of $40 \mathrm{mg}$, administered subcutaneously every 2 weeks (Brasil, 2013). The Brazilian Ministry of Health has not yet established a Clinical Protocol and Therapeutic Guidelines for AS nor PsA.

The patients were interviewed and examined when the drugs were dispensed by SUS, and the data were collected in a standard form and stored in databases. The sociodemographic variables assessed were age, sex, marital status, education and race.

Regarding the clinical variables, the type and duration of the disease since diagnosis were investigated. Furthermore, the Bath Ankylosing Spondylitis Disease Activity Index (BASDAI) (Garret et al., 1994) and the Clinical Disease Activity Index (CDAI) instruments (Aletaha, Smolen, 2005) were used to measure the disease activity. The patient's functional ability was assessed by the Heath Assessment Questionnaire-Disability Index (HAQ-DI) (Bruce, Fries, 2003), and the overall quality of life was assessed by the EuroQoL-5 dimensions (EQ5D) (The Euroquol Group, 1990); both instruments were validated to Brazilian Portuguese (Ferraz et al., 1990; Andrade et al., 2012). The HAQ-DI is a quantitative measurement of functionality with the following eight categories: hygiene, walking, gripping, arising, reaching, dressing and grooming, eating and daily activities. The HAQ-DI score assesses the difficulty in performing such tasks and ranges from 0 (no difficulty) to 3 (unable to perform) (Ferraz et al., 1990). The CDAI is an index for disease activity assessment and comprises the evaluation of pain and swelling of the shoulder, elbow, wrist, knee, metacarpophalangeal and proximal interphalangeal joints (Aletaha, Smolen, 2005). The disease activity in AS has been evaluated using BASDAI, which is a self-reporting tool focused on fatigue, axial pain, peripheral pain, enthesopathy and morning stiffness, as assessed by the Visual Analogue Scale (VAS) 0-10 (Garret et al, 1994). The EQ-5D health questionnaire is a generic tool to assess the quality of life that identifies 243 possible states of health, based on 5 dimensions: mobility, self-care, usual activities, pain/discomfort and anxiety/depression, with 3 alternatives for each (The Euroquol Group, 1990; Lubeck, 2004).

The data regarding the medications currently in use, including non-steroidal anti-inflammatory drugs (NSAIDs), disease-modifying antirheumatic drugs (DMARDs), corticosteroids and biological agents were recorded.

All patients signed an Informed Consent Form for participation in the study. The study was approved by the Research Ethics Committee of the Federal University of Minas Gerais (Comitê de Ética em Pesquisa da Universidade Federal de Minas Gerais - COEP-UFMG) under No. 0069.0.203.000-11.

\section{Statistical analysis}

The descriptive data were presented as means [standard deviation (SD)] for continuous variables, and as absolute frequencies and percentages for categorical variables for the entire study population. Comparisons of continuous and categorical variables between groups of diseases were obtained using an analysis of variance (ANOVA) and the chi-square test, respectively.

In the gender-stratified analysis, Student's t-test was used for the continuous variables, and the Pearson chisquare test was used for the categorical variables. 
To assess the link between selected variables and the functionality of patients initiating treatment, a multiple linear regression model was developed using the backward stepwise method, i.e. deleting variables until obtaining the final model. The HAQ-DI was adopted as a response variable, and the independent variables were sex, age, marital status, race, disease duration, rheumatic disease, biological agent and the EQ-5D data.

A Pearson correlation was performed for each group of diseases to test the relationship between the values obtained with the HAQ-DI, the quality of life assessment (EQ-5D) and disease activity tools (CDAI and BASDAI).

A significance level of $5 \%$ was adopted. The analyses were performed using the software SPSS 19 for Windows (IBM, Chicago, IL, USA).

\section{RESULTS AND DISCUSSION}

From March/2011 to December/2013, 302 patients who received a first dose of anti-TNF agents at SUS and that had agreed to participate were included in the study. The population consisted of $208(68.9 \%)$ patients with RA, $55(18.2 \%)$ patients with AS and 39 (12.9\%) patients with PsA.

Table I shows the demographic, clinical and drug use characteristics when the drugs were first dispensed. There was a predominance of female patients $(75.8 \%)$, while 151 patients $(51.3 \%)$ were Caucasian. The mean age (SD) was 50.3 (12.8) years, and the mean (SD) disease duration was 9.9 (8.7) years.

One hundred and six (35.1\%) patients had a high school-level education. Most participants used ADA $(70.9 \%)$, while $23.8 \%$ of the patients used ETA, and $5.3 \%$ used INF. The proportion of PsA patients using INF was higher than in the other two conditions $(\mathrm{p}=0.015)$. Concomitantly, $131(43.4 \%)$ participants used methotrexate (MTX); 204 (67.5\%) concomitantly used glucocorticoid, and 101 (33.4\%) concomitantly used NSAIDs. Significant differences regarding the concomitant use of medications were found between the

TABLE I - Baseline demographic and clinical characteristic for all population and According to rheumatic disease

\begin{tabular}{|c|c|c|c|c|c|}
\hline Characteristic & All (302) & AR (208) & PsA (39) & $\mathrm{AS}(55)$ & p-value \\
\hline Age, mean \pm SD years & $50,33 \pm 12,8$ & $51,62 \pm 13,32$ & $52,15 \pm 9,96$ & $44,16 \pm 10,71$ & $<0,001$ \\
\hline Female $(\%)$ & $229(75,8)$ & $185(88,9)$ & $25(64,1)$ & $19(34,5)$ & $<0,001$ \\
\hline White $(\%)$ & $155(51,3)$ & $100(48,1)$ & $25(64,1)$ & $30(54,5)$ & 0,161 \\
\hline Disease duration, mean \pm SD years & $9,85 \pm 8,71$ & $10,09 \pm 8,36$ & $8,97 \pm 7,6$ & $9,53 \pm 10,73$ & 0,733 \\
\hline Married (\%) & $177(58,6)$ & $120(57,7)$ & $21(53,8)$ & $36(65,5)$ & 0,473 \\
\hline Education & & & & & 0,288 \\
\hline Illiterate (\%) & $1,0(0,3)$ & $1(0,5)$ & 0 & 0 & \\
\hline Read and write (\%) & $44(14,6)$ & $35(16,8)$ & $5(12,8)$ & $4(7,3)$ & \\
\hline Primary School (\%) & $56(18,5)$ & $41(19,7)$ & $5(12,8)$ & $10(18,2)$ & \\
\hline High School (\%) & $106(35,1)$ & $76(36,5)$ & $13(33,3)$ & $17(30,9)$ & \\
\hline College (\%) & $88(29,1)$ & $51(24,5)$ & $14(35,9)$ & $23(41,8)$ & \\
\hline nMissing (\%) & $7,0(2,3)$ & $4(1,9)$ & $2(5,1)$ & $1(1,8)$ & \\
\hline \multicolumn{6}{|l|}{ Current medication } \\
\hline Adalimumab (\%) & $214(70,9)$ & $148(71,2)$ & $26(66,7)$ & $40(72,7)$ & 0,805 \\
\hline Etanercept (\%) & $72(23,8)$ & $54(26,0)$ & $8(20,5)$ & $10(18,2)$ & 0,422 \\
\hline Infliximab (\%) & $16(5,3)$ & $6(2,9)$ & $5(12,8)$ & $5(9,1)$ & 0,015 \\
\hline Methotrexate (\%) & $131(43,4)$ & $100(48,1)$ & $15(38,5)$ & $16(29,1)$ & 0,033 \\
\hline Glucocorticoid(\%) & $204(67,5)$ & $171(82,2)$ & $11(28,2)$ & $22(40,0)$ & $<0,001$ \\
\hline NSAIDs (\%) & $101(33,4)$ & $76(36,5)$ & $5(12,8)$ & $20(36,4)$ & 0,014 \\
\hline \multicolumn{6}{|l|}{ Clinical features } \\
\hline BASDAI, mean \pm SD & $5,02 \pm 2,30$ & \# & $5,27 \pm 2,26$ & $4,83 \pm 2,32$ & 0,370 \\
\hline $\mathrm{CDAI}$, mean $\pm \mathrm{SD}$ & $29,85 \pm 16,32$ & $30,56 \pm 16,92$ & $26,90 \pm 14,80$ & $*$ & 0,208 \\
\hline HAQ-DI, mean \pm SD & $1,37 \pm 0,67$ & $1,45 \pm 0,68$ & $1,30 \pm 0,64$ & $1,12 \pm 0,59$ & 0,003 \\
\hline $\mathrm{EQ}-5 \mathrm{D}$, mean $\pm \mathrm{SD}$ & $0,59 \pm 0,18$ & $0,58 \pm 0,18$ & $0,61 \pm 0,17$ & $0,63 \pm 0,18$ & 0,337 \\
\hline
\end{tabular}

\# BASDAI (Bath Ankylosing Spondylitis Disease Activity Index) was applied only for PsA and AS patients; *CDAI (Clinical Disease Activity Index) was applied only for RA and PsA patients; NSAIDs (Non-Steroidal Anti-Inflammatory Drug); HAQ-DI (Health Assessment Questionnaire-Disability Index); EQ-5D (EuroQol-five dimensions). 
diseases; RA patients used more MTX $(\mathrm{p}=0.033)$ and corticosteroids $(p=<0.001)$ than the patients with other diseases, and PsA patients used less NSAIDs than the patients with RA or AS.

The BASDAI values were $>4$ for AS and PsA patients, suggesting a high disease activity in patients at the beginning of treatment. The CDAI values were $>22$ for both RA and PsA patients, which indicate a high disease activity, with no significant difference between these groups $(\mathrm{p}=0.208)$.

The patients' functionality, measured with the HAQDI, was assessed at a mean score (SD) of 1.37 (0.67) for all of the participants at the beginning of treatment. Regarding the HAQ-DI score, the RA patients had a higher mean value (SD) of $1.45(0.68)$, and the AS patients had the lowest mean value at $1.12(0.59)$, with a significant difference among the three diseases $(\mathrm{p}=0.003)$. The mean value (SD) of the EQ-5D scores for the entire cohort was $0.59(0.18)$ with no significant statistical difference among the three diseases $(\mathrm{p}=0.337)$.

The main comorbidities found among the patients were systemic arterial hypertension (37.7\%), depression (21.9\%), dyslipidemia (18.5\%), osteoporosis (13.6\%), diabetes $(9.3 \%)$, obesity $(7.0 \%)$, chronic obstructive pulmonary disease $(3.6 \%)$ and gastric ulcer $(3.3 \%)$.

Table II shows the comparison of the baseline variables between sexes. The women were older $(\mathrm{p}=0.042)$, had a higher disease activity as measured by
CDAI $(p=0.039)$, had poorer functionality $(\mathrm{p} \leq 0.001)$ and had a higher frequency of ADA ( $\mathrm{p}=0.034), \operatorname{INF}(0.005)$ and corticosteroid $(p \leq 0.001)$ use compared to men.

Table III shows the final model of factors associated with a poorer functional response as measured by the HAQ-DI. The characteristics of being female, married and having an overall health status $<0.6$ (as assessed by EQ5D) are statistically associated with a poorer functional response. The variable of age, although this factor was not significantly associated with functionality, was kept in the final model because age was considered an important variable and had a borderline $p$-value.

Table IV lists the Pearson correlation coefficients between HAQ-DI values and the measurements of disease activity and quality of life. A significant correlation between the HAQ-DI values and the disease activity and quality of life measurements $(p<0.01)$ was observed for the three groups of patients evaluated.

\section{DISCUSSION}

This cross-sectional study is part of an open prospective cohort with Brazilian Public Health System patients in the city of Belo Horizonte, Minas Gerais, Brazil. Patients with RA, AS and PsA treated at SUS were mostly women and Caucasian with a mean age of 50.3 years. The mean disease duration was 9.9 years, reflecting established disease. At the beginning of the

TABLE II - Patients characteristics according to sex. Data reflecting baseline status

\begin{tabular}{lccc}
\hline Variable & $\begin{array}{c}\text { Female } \\
\mathrm{n}=229\end{array}$ & Male & $\mathrm{P}$ \\
& Mean $\pm \mathrm{SD}$ or $\%$ & Mean $\pm \mathrm{SD}$ or $\%$ & 0,042 \\
\hline Age, years & $51,77 \pm 12,80$ & $47,69 \pm 12,52$ & 0,985 \\
Disease duration, years & $9,85 \pm 8,46$ & $9,83 \pm 9,52$ & 0,039 \\
CDAI* & $30,78 \pm 16,70$ & $24,90 \pm 14,90$ & 0,432 \\
BASDAI** & $5,22 \pm 2,37$ & $4,84 \pm 2,24$ & $<0,001$ \\
HAQ-DI, & $1,47 \pm 0,65$ & $1,07 \pm 0,64$ & 0,088 \\
EQ-5D & $0,59 \pm 0,18$ & $0,63 \pm 0,19$ & 0,034 \\
Adalimumab use & $169(73,8)$ & $45(61,6)$ & 0,360 \\
Etanercept use & $53(23,1)$ & $19(26,0)$ & 0,005 \\
Infliximab use & $7(3,0)$ & $5(7,0)$ & 0,196 \\
Methotrexate use & $103(45,0)$ & $28(38,4)$ & $<0,001$ \\
Corticosteroid use & $173(75,5)$ & $31(42,5)$ & 0,079 \\
NSAIDs use & $82(35,8)$ & $19(26,0)$ & \\
\hline
\end{tabular}

*For CDAI (Clinical Disease Activity Index) only 212 female and 40 male patients were assessed; **For BASDAI (Bath Ankylosing Spondylitis Disease Activity Index) only 44 female and 50 male patients were assessed); HAQ-DI (Health Assessment Questionnaire-Disability Index); EQ-5D (EuroQol-five dimensions); NSAIDs (Non-Steroidal Anti-Inflammatory Drug). 
TABLE III - Baseline characteristics multivariate predictors of a poor functional status

\begin{tabular}{lcccc}
\hline Baseline variable & $\mathrm{n}$ & $\beta$ coefficient & $\mathrm{p}$ & $95 \%$ CI \\
\hline $\begin{array}{l}\text { Sex } \\
\text { Female }\end{array}$ & 73 & & & \\
$\quad$ Male & 229 & Ref. & $<0,001$ & {$[-0,464 ;-0,181]$} \\
$\begin{array}{l}\text { Social status } \\
\quad \text { Married }\end{array}$ & $-0,322$ & & \\
$\quad$ Others & 172 & & & \\
EQ-5D & 125 & Ref. & 0,013 & {$[-0,275 ;-0,033]$} \\
$\quad<0,60$ & & $-0,154$ & & \\
$\quad \geq 0,60$ & 129 & & & \\
Age, years & 173 & $-0,756$ & & {$[-0,878 ;-0,635]$} \\
$\quad<50$ & & & & \\
$\geq 50$ & 142 & Ref. & 0,065 & {$[-0,009 ; 0,231]$} \\
\hline
\end{tabular}

CI (confidence Interval); EQ-5D (EuroQol-five dimensions).

TABLE IV - Correlation (Pearson $r$ values) between HAQ-DI score, EQ-5D and disease activity instruments according patient group

\begin{tabular}{lcccc}
\hline & BASDAI & CDAI & EQ-5D & $\mathrm{p}$-value \\
\hline \multirow{3}{*}{ HAQ-DI } & $*$ & 0,648 & $-0,742$ & $\mathrm{P}<0,01$ \\
& 0,591 & 0,597 & $-0,711$ & $\mathrm{P}<0,01$ \\
& 0,63 & $* *$ & $-0,69$ & $\mathrm{P}<0,01$ \\
\hline
\end{tabular}

*BASDAI (Bath Ankylosing Spondylitis Disease Activity Index) was not applied to RA patients; **CDAI (Clinical Disease Activity Index) was no applied to AS patients; HAQ-DI (Health Assessment Questionnaire-Disability Index); EQ-5D (EuroQolfive dimensions).

study, the patients had high levels of disease activity, and the functionality characterised them as having moderate to severe functional difficulty and an intermediate quality of life.

Our data on the participants' profiles are in accordance with a study that implemented a database on the use of biological agents in Brazil (BIOBADABRASIL) (Titton et al., 2011), which showed a predominance of female RA patients with mean disease duration of $10 \pm$ 8.2 years. A possible explanation for the prevalence of RA patients is the absence of an appropriate Clinical Protocol and Therapeutic Guidelines publication in Brazil to aid in the treatment of patients with AS and PsA.

In Brazil, the use of biological agents is not indicated to early disease, DMARD-naïve patients. The similar mean disease duration found in the present study and in the BIOBADABRASIL study demonstrate that there is a trend within the Brazilian population regarding the average time that it takes to begin treatment with biological agents. Another Brazilian study (Soares et al., 2012) with RA patients obtained a mean age and prevalence of women similar to the present study. However, that study had higher mean disease duration.

Another BIOBADABRASIL study (Fafá et al., 2015), evaluated drug survival and reasons for discontinuation of anti-TNF $\alpha$ drugs, in AS and RA patients. The study included a large number of patients (372 AS, $931 \mathrm{RA}$ ) and found similar baseline demographic characteristics. For the AS cohort, that study found a mean age of $43.7 \pm 11.9$ years and $80,1 \%$ of the participants were women. Also, for the RA cohort, the mean age was $53.2 \pm 11.9$ years, being the majority of the participants female $(86 \%)$.

The data from an observational study of RA patients conducted in Sweden in 2008 (Karlsson et al., 2008) also revealed similar baseline characteristics, with patients with a mean age of 56 years and $82 \%$ female participants; however, the mean duration of disease was also higher, $14 \pm 10$ years. Longer mean disease duration can be the result of requiring patients to show greater disease activity as a condition for the initial drugs delivery, given that the clinical disease parameters further evolve over a longer 
period of time in the presence of symptoms and due to the fact that these diseases are difficult to early diagnose. Two observational studies investigating the introduction of biological therapy in patients with a disease activity score $>5.1$ as measured by the Disease Activity Score in 28 Joints instrument (DAS-28), one conducted in Lombardia (Fillipini et al., 2010) in 2010 and another one conducted in UK in 2008 (Hyrich et al., 2008), found mean disease duration values greater than that found in our study, which followed the Clinical Protocol and Therapeutic Guidelines for RA from the Brazilian Ministry of Health, which considers a DAS-28 score $>3.2$ as the initial parameter of disease activity.

The BASDAI and CDAI values revealed a high disease activity when an anti-TNF agent was first used, which is consistent with the indication to use biological medications. Patients presented mean values of HAQDI from moderate to high (Bruce, Fries, 2003). Similar functionality and disease activity according to the BASDAI were found in a descriptive study of individuals with spondyloarthritis in Egypt (Tayel et al., 2012), which found BASDAI values $>4$ and an HAQ-DI value in the range of 1-2. Therefore, at the beginning of treatment, these patients had moderate to high functional impairment and a high disease activity according to BASDAI.

The patients in our study had an intermediate quality of life as measured by EQ-5D, given that this score ranges from $0-1$, being 1 the best possible quality of life. Two studies, one in South Korea in 2008 (Choi et al., 2008) and another one in the Netherlands in 2010 that were based on the DREAM patient register (Kievit et al., 2011) and used the same instrument, had similar results when patients were evaluated at the beginning of treatment, 0.5 (SD 0.2) and 0.56 (SD 0.3) respectively. Thus, it is important to note that our study shown similar quality of life results to that found in studies conducted abroad.

When comparing groups of patients according to their rheumatic diseases, there were differences between sex, age and functional capacity that can be related to the prevalence of women in the group of RA patients and the greater presence of men in the group of AS patients. We found that women has poor baseline clinical results when compared to men. Regarding gender and age, the data from a Norwegian register study conducted in 2008 (Heiberg et al., 2008) that evaluated the treatment compliance rate with anti-TNF agents in RA, PsA and AS patients showed that the group of RA patients was older than the PsA and AS patient groups. In addition, a higher percentage of women was found in the RA group, and a higher percentage of men was found in the AS group. That study revealed that men have a better functional status than women and are younger, which was also observed in the present study.

At the beginning of treatment, a poorer functionality was associated with female gender, married patients and with a poor quality of life. Similar findings were found in an observational cohort study performed in the UK in 2013, in which poorer functionality was found in women, patients with advanced age at diagnosis, with a long duration of symptoms and those who had a history of smoking or previous treatment (Tillet et al., 2013).

Functionality assessment is necessary because it is a factor that impacts work absenteeism. In a study conducted in Germany (Kruger et al., 2012), patients with a high number of absences from work in the previous year due to the disease had a worse prognosis.

There was a correlation between functionality and the indices of disease activity and quality of life. A positive correlation was observed between HAQ-DI and disease activity indices (BASDAI and CDAI), and a negative correlation between HAQ-DI and EQ-5D score was also observed. High BASDAI and CDAI values characterise high disease activity; consequently, these high values were associated with a poorer functional response.

The patients with a poorer functional response had a lower quality of life. An Italian observational study (Picchianti-Diamanti et al., 2010) evaluating the quality of life using the Short-form 36 Health Status (SF-36) questionnaire in RA and PsA patients, conducted in 2010, also found a significant positive correlation between functionality measured by HAQ-DI and disease activity measured by DAS in 44 joints.

This study shows important aspects that reflect directly in the social aspects of the diseases and in the academic environment and political decisions. As mentioned by Cavalcanti 2010, Brazilian patients with rheumatic disease suffer with many access barriers, such as reduced number of rheumatology units, few medical specialists, inadequate transportation and little availability of medication in Brazilian National Health System. All of these aspects mentioned above can directly influence on patient's prognosis and behavior. Thus, it is important to note that our study has considered beyond the direct increases in disease severity and activity, the patient's functionality and health-related QOL status.

Given the chronic nature of those diseases, the main goals of treatment are to reduce symptoms, preserve the functional capacity of patients and improve their QOL. Recent studies showed that QOL indicators are relevant predictors of functionality and other relevant health outcomes in individuals with rheumatic conditions (Gordeev et al., 2010, Alava et al., 2013, Ariza-Ariza 
et al., 2009, Gaujoux-Viala et al., 2013). In Brazil, few studies has assessed QOL in patients with RA (Pinheiro et al., 2013, Da Mota et al., 2012). Pinheiro et al. (2013) conducted a cross-sectional study evaluating QOL and functionality results in RA patients. That study found that health status deteriorated as disease severity increased with worsening disability, pain, fatigue, quality of life and perceived general health status. It is important to note that we have exactly analysed patients with high functional and quality of life impairment. Da Mota et al. (2012) conducted a prospective cohort with early rheumatoid arthritis patients to investigate the capacity of prediction of baseline functionality and QOL measures. The mean baseline HAQ score was 1.89 at baseline, improving to 0.77 by the third year $(\mathrm{P}<0.0001)$. Most SF-36 domains showed significant improvement except for general state and vitality. That study also concluded that biological therapy was deemed necessary in $22.5 \%$ of patients. The initial HAQ and SF-36 scores were not associated with clinical remission, bone erosions or the need for biological therapy at 36 months. Thus, it is important to consider baseline results as potential predictors of clinical features, during biological therapy.

The study population was selected through convenience sampling. One limitation of this method is that only patients able to visit the service participated in the study. Thus, more severe cases and older adults may not have been included in the study. Although this study was not planned to represent the Brazilian population, what can be considered a limitation, its results reflect the impact of the knowledge of the diseases and in living with them. Furthermore, we present similar clinical and demographic results compared to another Brazilian studies (Pinheiro et al., 2013; Da Mota et al., 2012, De Oliveira Junior et al., 2015; De Azevedo et al., 2008; De Souza et al., 2011; Da Mota et al., 2010). All of these studies have predominantly presented patients with RA, women, married and Caucasians. In addition, in all of it the participants presented moderate to severe disability as measured by HAQ-DI.

\section{CONCLUSION}

The present study evaluated the use profiles of anti-TNF agents in RA, PsA and AS patients treated by Brazilian Public Health System. The results showed that patients with one of these three diseases had a high disease activity at the start of biological therapy. Patients with RA had a poorer functional status than patients with PsA and AS. Furthermore, being female, being married and having a quality of life value $<0.6$ as measured by EQ-5D was associated with a poorer functionality at the beginning of treatment. In countries with a universal health care system, as in Brazil, it is crucial to understand the patients' characteristics and the results of incorporating this therapeutic modality (anti-TNF agents). This knowledge can assist in ensuring excellent service to the population and enable the optimisation of public resources use, improvements in pharmaceutical services and planning of future actions. Future analyses entailing a prospective follow-up will be performed, given that an observational and prospective study is in progress.

\section{ACKNOWLEDGMENTS}

To the National Council for Scientific and Technological Development-CNPq and to Minas Gerais Research Support Foundation-FAPEMIG

\section{REFERENCES}

ALAVA, M.H.; WAILOO, A.; WOLFE, F.; MICHAUD, K. The relationship between EQ-5D, HAQ and pain in patients with rheumatoid arthritis. Rheumatology, v.52, n.2, p.944-950, 2013.

ALETAHA, D.; SMOLEN, J. The simplified disease activity index (SDAI) and clinical disease activity index (CDAI): a review of their usefulness and validity in rheumatoid arthritis. Clin. Exp. Rheumatol., v.23, supl.39, p.100-108, 2005.

AMERICAN COLLEGE OF RHEUMATOLOGY Subcommittee on rheumatoid arthritis guidelines. Guidelines for the management of rheumatoid arthritis. Arthritis Rheum., v.46, n.2, p.328-346, 2002.

ANDRADE, M.V.; NORONHA, K.; DE BARROS REIS, C.; DE MENEZES, R.M.; MARTINS, D.; NEPOMUCENO, M.; BIET, A.; NICHELE, D.; GOMES, L.; CARVALHO, L.; CALAZANS, J.; VILHENA, T. Sistemas de valores do instrumento EQ-5D de mensuração da qualidade de vida relacionada à saúde: uma análise para o estado de Minas Gerais. Grupo de Estudos em Economia da Saúde e Criminalidade, Centro de Desenvolvimento e Planejamento Regional - CEDEPLAR, Universidade Federal de Minas Gerais, 2012. Avaiable at: <http://www.researchgate.net/ publication/266416984 SISTEMA DE VALORES DO_INSTRUMENTO_EQ-5D_DE_MENSURAO_DE QUALIDADE_DE_VIDA_RELACIONADA_SADE_ UMA_ANLISE_PARA_O_ESTADO_DE_MINAS GERAIS>. Accessed on: Ago. 2015. 
ARIZA-ARIZA, R.; HERNÁNDEZ-CRUZ, B.; LÓPEZANTEQUERA, G.; NAVARRO-SARABIA, F. Variables related to utility in patients with ankylosing spondylitis. Clin. Rheumatol., v.28, n.2, p.207-211, 2009.

ARNETT, F.C.; EDWORTHY, S.M.; BLOCK, D.A.; MCSHANE, D.J.; FRIES, J.F.; COOPER, N.S.; HEALEY, L.A.; KAPLAN, S.R.; LIANG, M.H.; LUTHRA, H.S.; MEDSGER, T.A.; MICHELL, D.M.; NEUSTADT, D.H.; PINALS, R.S.; SCHALLER, J.G.; SHARP, J.T.; WILDER, R.L.; HUNDER, G.G. The American Rheumatism Association 1987 revised criteria for classification of rheumatoid arthritis. Arthritis Rheum., v.31, n.3, p.315-324, 1988.

BRASIL. Ministério da Saúde. Protocolo Clínico e Diretrizes Terapêuticas Artrite Reumatoide; PORTARIA N ${ }^{\circ} 710$, de 27 de junho de 2013.

BRASIL. Portaria Ministério da Saúde. Ministério da Saúde, Diário Oficial da União 7, 2008.

BRUCE, B.; FRIES, J.F. The stanford health assessment questionnaire: a review of its history, issues, progress, and documentation. J. Rheumatol., v.30, n.1, p.100-108, 2003.

CANADIAN AGENCY FOR DRUGS AND TECHNOLOGIES IN HEALTH-CADTH. Issues in emerging health technologies: rituximab for rheumatoid arthritis. CADTH, 2006. Available at: $<$ https://www.cadth. ca/media/pdf/E0001_rituximab_cetap_e.pdf $>$. Accessed on: Ago. 2015.

CARBONE, L.D.; COOPER, C.; MICHET, C.J.; ATKINSON, E.J.; O'FALLON, W.M.; MELTON, J. Ankylosing spondylitis in Rochester Minnesota 1935-1989. Arthritis Rheum., v.35, n.12, p.1476-1482, 1992.

CAVALCANTI, F.S. Management of rheumatoid diseases: the Brazilian perspective. Rheumatology, v.49, n.2, p.22312232, 2010.

CHOI, C.B.; KIM, T.J.; PARK, H.J.; UHM, W.S.; JUN, J.B.; BAE, S.C.; YOO, D.H.; KIM, T.H. Safety and clinical responses in ankylosing spondylitis after three months of etanercept therapy. J. Korean Med. Sci., v.23, n.5, p.852$856,2008$.

CHORUS, A.M.J.; BOONEN, A.; MIEDEMA, H.S.; VAN DER LINDEN, S. Employment perspectives of patients with ankylosing spondylitis. Ann. Rheum. Dis., v.61, n.8, p.693-699, 2002.
DA MOTA, L.M.H.; DOS SANTOS NETO, L.L.; OLIVEIRA, A.C.V.; PEREIRA, I.A.; BURLINGAME, R.W.; MENARD, H.A.; LAURINDO, I.M.M. Baseline HAQ and SF-36 questionnaire scores cannot predict clinical remission, radiographic progression or the need for biological therapy in a three-year prospective study of a Brazilian early rheumatoid arthritis cohort. Rheumatol. Int., v.32, n.12, p.3937-3943, 2012.

DA MOTA, L.M.H.; LAURINDO, I.M.M.; DOS SANTOS NETO, L.L. Avaliação prospectiva da qualidade de vida em uma coorte de pacientes com artrite reumatoide inicial. Rev. Bras. Reumatol., v.50, n.3, p.249-261, 2010.

DE AZEVEDO, A.B.C.; FERRAZ, M.B.; CICONELLI, R.M. Indirect costs of rheumatoid arthritis in Brazil. Value Health, v.11, n.5, p.869-877, 2008.

DE OLIVEIRA JUNIOR, H.A.; DOS SANTOS, J.B.; ACURCIO, F.A.; ALMEIDA, A.M.; KAKEHASI, A.M.; ALVARES, J.; DE CARVALHO, L.F.D.; CHERCHIGLIA, M.L. Poorer functionality is related to better quality of life response following the use of biological drugs: 6-month outcomes in a prospective cohort from the Public Health System (Sistema Único de Saúde), Minas Gerais, Brazil. Expert Rev. Pharmacoecon. Outcomes Res., v.15, n.3, p.403-412, 2015.

DE SOUZA, M.C.; DE ÁVILA FERNANDES, E.; JONES, A.; LOMBARDI JR, I.; NATOUR, J. Assessment of cervical pain and function in patients with rheumatoid arthritis. Clin. Rheumatol., v.30, n.6, p.831-836, 2011.

FAFÁ, B.P.; LOUZADA-JUNIOR, P.; TITTON, D.C.; ZANDONADE, E.; RANZA, R.; LAURINDO, I.; PEÇANHA, P.; RANZOLIN, A.; HAYATA, A.L.; DUARTE, A.; SILVEIRA, I.G.; COSTA, I.; MACIEIRA, J.C.; GUEDES-BARBOSA, L.S.; BERTOLO, M.B.; SAUMA, M.F.L.C.; SILVA, M.B.G.; FREIRE, M.; SCHEINBERG, M.A.; FERNANDES, V.; BIANCHI, W.; MIRANDA, J.R.S.; PINHEIRO, G.R.C.; CARVALHO, H.M.S.; BRENOL, C.V.; PEREIRA, I.A.; DE CASTRO, G.R.W.; DE MORAIS, J.C.B.; OLIVEIRA, S.K.F.; DE ABREU, M.M.; TOLEDO, R.A.; PINHEIRO, M.M.; VIEIRA, W.P.; VALIM, V. Drug survival and causes of discontinuation of the first anti-TNF in ankylosing spondylitis compared with rheumatoid arthritis: analysis from BIOBADABRASIL. Clin. Rheumatol. v.34, n.5, p.921-927, 2015. 
FERRAZ, M.B.; OLIVEIRA, L.M.; ARAUJO, P.M.; ATRA, E.; TUGWELL, P. Crosscultural reliability of the physical ability dimension of the health assessment questionnaire. J. Rheumatol., v.17, n.6, p.813-817, 1990.

FIL L IPINI, M.; BAZZANI，C.; FAVALLI, E.G.; MARCHESONI, A.; ATZENI, F.; SARZI-PUTTINI, P.; PALLAVICINI, F.B.; CAPORALI, R.; GORLA, R. Efficacy and safety on anti-tumor necrosis factor in elderly patients with rheumatoid arthritis: an observational study. Clinic. Rev. Allergy Immunol., v.38, n.2-3, p.90-96, 2010.

GAUJOUX-VIALA, C.; FAUTREL, B.; GUILLEMIN, F.; FLIPO, R.M.; BOURGEOIS, P.; RAT, A.C. Who are the patients with early arthritis with worse than death scores on the EQ-5D? Results from the ESPOIR cohort. Rheumatology, v.52, n.5, p.832-838, 2013.

GARRET, S.; JENKINSON, T.; KENNEDY, L.G.; WHiTELOCK, H.; GAISFORD, P.; CALIN, A. A new approach to defining disease status in ankylosing spondylitis: the bath ankylosing spondylitis disease activity index. J. Rheumatol., v.21, n.12, p.2286-2291, 1994.

GLADMAN, D.D. Psoriatic arthritis. Baillières Clin. Rheumatol., v.9, n.2, p.319-329, 1995.

GOMOR, B.; GYODI, E.; BAKOF, L. Distribution of HLA-B27 and ankylosing spondylitis in the Hungarian population. J. Rheumatol., v.4, suppl.3, p.33-35, 1977.

GORDEEV, V.S.; MAKSYMOWYCH, W.P.; EVERS, S.M.; AMENT, A.; SCHACHNA, L.; BOONEN, A. Role of contextual factors in health-related quality of life in ankylosing spondylitis. Ann. Rheum. Dis., v.69, n.1, p.108$112,2010$.

HEIBERG, M.S.; KOLDINGSNES, W.; MIKKELSEN, K.; RØDEVAND, E.; KAUFMANN, C.; MOWINCKEL, P.; KVIEN, T.K. The comparative one-year performance of anti-tumor necrosis factor $\alpha$ drugs in patients with rheumatoid arthritis, psoriatic arthritis and ankylosing spondylitis: results from a longitudinal, observational, multicenter, study. Arthritis Rheum., v.59, n.2, p.234-240, 2008.

HYRICH, K.L.; LUNT, M.; DIXON, W.G.; WATSON, K.D.; SYMMONS, D.P.M. Effects of switching between antiTNF therapies on HAQ response in patients who do not respond to their first anti-TNF. Rheumatology, v.47, n.7, p.1000-1005, 2008.
KARLSSON, J.A.; KRISTENSEN, L.E.; KAPETANOVIC, M.C.; GÜLFE, A.; SAXNE, T.; GEBOREK, P. Treatment response to a second or third TNF-inhibitor in RA: results from the south swedish arthritis rheumatoid treatment group register. Rheumatology, v.47, n.4, p.507-513, 2008.

KIEVIT, W.; FRANSEN, J.; ADANG, E.M.M.; DEN BROEDER, A.A.; MOENS, H.J.B.; VISSER, H.; VAN DE LAAR, M.A.F.; VAN RIEL, P.L.C.M. Long-term effectiveness and safety of TNF blocking agents in daily clinical practice: results from the ducth rheumatoid arthritis register. Rheumatology, v.50, n.1, p.196-203, 2011.

KRUGER, K.; WOLLENHAUPT, J.; LORENZ, H.M.; RÖTHER, E.; WITTIG, B.M. Reduction in sickness absence in patients with rheumatoid arthritis receiving adalimumab: data from a german noninterventional study. Rheumatol. Int., v.32, n.12, p.3977-3983, 2012.

LIPSKY, P.E.; VAN DER HEIJDE, D.M.; ST CLAIR, E.W.; FURST, D.E.; BREEDVELD, F.C.; KALDEN, J.R.; SMOLEN, J.S.; WEISMAN, M.; EMERY, P.; FELDMANN, M.; HARRIMAN, G.R.; MAINI, R.N. Infliximab and methotrexate in the treatment of rheumatoid arthritis. Anti-tumor necrosis factor trial in rheumatoid arthritis with concomitant therapy study group. N. Engl. J. Med., v.343, n.22, p.1594-1602, 2000.

LUBECK, D.P. Patient-reported outcomes and their role in the assessment of rheumatoid arthritis. Pharmacoeconomics, v.22, suppl.1, p.27-38, 2004.

MARQUES NETO, J.F.; GONÇALVES, E.T.; LANGEN, L.F.O.B.; CUNHA, M.F.L.; RADOMINSKI, S.; OLIVEIRA, S.M.; CURY, S.E.; MEDEIROS, F.; SAMPAIO, G.C. Estudo multicêntrico da prevalência da artrite reumatoide do adulto em amostras da população brasileira. Rev. Bras. Reumatol., v.33, n.2, p.169-173, 1993.

MOLL, J.M.H.; WRIGHT, V. Psoriatic arthritis. Semin. Arthritis. Rheum., v.3, n.1, p.55-78, 1973.

NATIONAL INSTITUTE FOR HEALTH AND CLINICAL EXCELLENCE. NICE. Rheumatoid arthritis in adults. NICE, 2009.

PICCHIANTI-DIAMANTI, A.; GERMANO, V.; FERLITO, C.; MigliORE, A.; D’AMELIO, R.; LAGANÀ, B. Health-related quality of life and disability in patients with rheumatoid, early rheumatoid and psoriatic arthritis treated with etanercept. Qual. Life Res., v.19, n.6, p.821-826, 2010. 
PINHEIRO, G.R.C.; KHANDKER, R.K.; SATO, R.; ROSE, A.; PIERCY, J. Impact of rheumatoid arthritis on quality of life, work productivity and resource utilisation: an observational, cross-sectional study in Brazil. Clin. Exp. Rheumatol., v.31, n.3, p.334-340, 2013.

SAMPAIO-BARROS, P.D.; AZEVEDO, V.F.; BONFIGLIOLI, R.; CAMPOS, W.R.; DA SILVA CARNEIRO, S.C.; CARVALHO, M.A.P.; GONÇALVES, C.R.; HILÁRIO, M.O.E.; KEISERMAN, M.W.; LEITE, N.H.; MALLMANN, K.; DE SOUZA MEIRELLES, E.; VIEIRA, W.P.; XIMENES, A.C. First update on the brazilian consensus for the diagnosis and treatment of spondyloarthropathies: ankylosing spondylitis and psoriatic arthritis. Rev. Bras. Reumatol., v.47, n.4, p.233-242, 2007.

SECRETARIA DE ESTADO DE SAÚDE DO ESTADO DE MINAS GERAIS. Sistema de Informação e Gestão Hospitalar - SIGH, 2013.

SENNA, E.R.; DE BARROS, A.L.; SILVA, E.O.; COSTA, I.F.; PEREIRA, L.V.; CICONELLI, R.M.; FERRAZ, M.B. Prevalence of rheumatic diseases in Brazil: a study using the COPCORD approach. J. Rheumatol., v.31, n.3, p.594$597,2004$.

SOARES, M.R.M.P.; DOS REIS NETO, E.T.; LUZI, K.R.; CICONELLI, R.M.; PINHEIRO, M.M. Estratégia de troca entre agentes anti-TNF-alfa não melhora a capacidade funcional em pacientes com artrite reumatoide de longa duração. Rev. Bras. Reumatol., v.52, n.1, p.3-15, 2012.

ST CLAIR, E.W.; VAN DER HEIJDE, D.M.; SMOLEN, J.S.; MAINI, R.N.; BATHON, J.M.; EMERY, P.; KEYSTONE, E.; SCHIFF, M.; KALDEN, J.R.; WANG, B.; DEWOODY, K.; WEISS, R.; BAKER, D. Combination of infliximab and methotrexate therapy for early rheumatoid arthritis: a randomized, controlled trial. Arthritis Rheum., v.50, n.11, p.3432-3443, 2004.
TAYEL, M.Y.; SOLIMAN, E.; EL BAZ, W.F.; EL LABAAN, A.; HAMAAD, Y.; AHMED, M.H. Registry of the clinical characteristics of spondyloarthritis in a cohort of egyptian population. Rheumatol. Int., v.32, n.9, p.2837-2842, 2012.

TAYLOR, W.; GLADMAN, D.; HELLIWELL, P.; MARCHESONI, A.; MEASE, P.; MIELANTS, H. Classification for psoriatic arthritis: development of new criteria from a large international study. Arthritis Rheum., v.54, n.8, p.361-368, 2006.

THE EUROQOL GROUP. EuroQuol a new facilty for the measurement of health-related quality of life. Health Policy, v.16, n.3, p.199-208, 1990.

TILLET, W.; JADON, D.; SHADDICK, G.; CAVILL, C.; KORENDOWYCH, E.; DE VRIES, C.S.; MCHUGH, N. Smoking and delay to diagnosis are associated with poorer functional outcome in psoriatic arthritis. Ann. Rheum. Dis., v.17, n.8, p.1358-1361, 2013.

TITTON, D.C.; SILVEIRA, I.G.; LOUZADA-JUNIOR, P.; HAYATA, A.L.; CARVALHO, H.M.S.; RANZA, R.; REZENDE, L.S.; PINHEIRO, G.C.; SANTOS, J.L.F.; MIRANDA, J.R.; CARVALHO, J.F.; BERTOLO, M.B.; FREIRE, M.; SCHEINBERG, M.A.; SKARE, T.L.; FERNANDES, V.; BIANCHI, W.; LAURINDO, I.M.M. Registro brasileiro de biológicos: processo de implementação e resultados preliminares da BiobadaBrasil. Rev. Bras. Reumatol., v.51, n.2, p.145-160, 2011.

VAN DER LINDEN, S.; VALKENBURG, H.A.; CATS, A. Evaluation of diagnostic criteria for ankylosing spondylitis. A proposal for modification of the New York criteria. Arthritis Rheum., v.27, n.4, p.361-368, 1984.

WEST, H.F. The etiology of ankylosing spondylitis. Ann. Rheum. Dis., v.8, n.2, p.143-148, 1949.

Received for publication on $26^{\text {th }}$ June 2014 Accepted for publication on $28^{\text {th }}$ July 2015 
